\title{
Gastric Digestion of Milk Proteins in Adult and Elderly: Effect of High-Pressure Processing
}

\author{
Kataneh Aalaei*, Bekzod Khakimov (D), Cristian De Gobba and Lilia Ahrné \\ Department of Food Science, University of Copenhagen, Rolighedsvej 26, DK-1958 Frederiksberg, Denmark; \\ bzo@food.ku.dk (B.K.); gobba@food.ku.dk (C.D.G.); lilia@food.ku.dk (L.A.) \\ * Correspondence: kataneh@food.ku.dk
}

Citation: Aalaei, K.; Khakimov, B.; De Gobba, C.; Ahrné, L. Gastric Digestion of Milk Proteins in Adult and Elderly: Effect of High-Pressure Processing. Foods 2021, 10, 786. https://doi.org/10.3390/ foods10040786

Academic Editor:

Gianfranco Mamone

Received: 1 March 2021

Accepted: 29 March 2021

Published: 6 April 2021

Publisher's Note: MDPI stays neutral with regard to jurisdictional claims in published maps and institutional affiliations.

Copyright: (C) 2021 by the authors Licensee MDPI, Basel, Switzerland. This article is an open access article distributed under the terms and conditions of the Creative Commons Attribution (CC BY) license (https:// creativecommons.org/licenses/by/ $4.0 /)$

\begin{abstract}
Reduced physiological capability of the human gastrointestinal tract with increasing age has recently attracted considerable attention to the potential of novel technologies to modify food digestion. Thus, the aim of this study was to investigate gastric digestion of milk proteins after application of high-pressure processing (HPP) at $400 \mathrm{MPa} 15 \mathrm{~min}, 600 \mathrm{MPa} 5 \mathrm{~min}$ and $600 \mathrm{MPa}$ 15 min using two static in vitro models of adults (INFOGEST) and the elderly in comparison to a fresh untreated raw milk. Peptides distribution classified based on the number of amino acids (AA) $(<10$, 11-15, 16-20, 21-30, >30 AA) were investigated after 0, 5, 10 and $30 \mathrm{~min}$ of digestion using LC-MS and multivariate data analysis. Our results show significantly less efficient protein digestion of all investigated milks in the elderly model indicated by higher percentages of longer peptides during digestion, except for the HPP milk $400 \mathrm{MPa} 15 \mathrm{~min}$, which indicated an improved and comparable digestion in the elderly as in the adult model. Furthermore, increasing the pressurization time at $600 \mathrm{MPa}$ did not have a significant effect on the peptides profile during the digestion. More efficient digestion of whey proteins in HPP milks, with the majority of peptides in the 16-20 AA range, compared to fresh milk was also noticed. According to the findings of this study, HPP at $400 \mathrm{MPa}$ 15 min showed the most efficient digestion of major milk proteins and thus may be considered a suitable process to improve bioaccessibility of milk proteins, especially in products intended for the elderly.
\end{abstract}

Keywords: in vitro digestion; high-pressure processing; peptide distribution; INFOGEST; milk digestion

\section{Introduction}

In recent years, the application of novel processing technologies has attracted considerable attention in the food industry, and one of the most promising technologies has been high-pressure processing (HPP). This is mostly due to its potential in inactivation of undesired microorganisms and extending the products' shelf-life as well as preserving nutritional and organoleptic properties of the products [1]. Currently, there are a few commercial milk products on the market using this technology such as the so-called "cold press raw milk" patented [2] and manufactured in Australia (Made by cow ${ }^{\circledR}$ ) as well as HPP-treated cow and sheep milks produced in Mexico (Villa de Patos ${ }^{\circledR}$ ).

The capability of this technology for modification of milk proteins especially in model systems has been confirmed in several studies [3-10]. Dissociation of casein micelles into smaller submicelles and their subsequent reassociation has been reported and discussed in the literature $[7,9,11]$. Furthermore, structural modification of whey proteins, especially $\beta$-lactoglobulin $(\beta-\mathrm{Lg})$, has been reported $[8,12,13]$. Based on these studies pressure intensity, temperature, time, $\mathrm{pH}$, and concentration of the protein are the factors determining the extent of subsequent denaturation or aggregation of milk proteins.

The impact of traditional dairy processing on gastrointestinal digestion of the products has been well established in the literature [14-24]. However, to our knowledge, there are only very few studies that have investigated the digestion of milk proteins after application 
of novel technologies such as HPP. The effect of HPP on in vitro digestion of $\beta$-Lg $[4,25]$, whey protein isolate (WPI) [25], $\alpha$-casein [26], and whole milk [27] has so far been reported. Increasing the pressure in the range 100-400 MPa led to an increase in tryptic hydrolysis of $\beta-\mathrm{Lg}$, with the highest hydrolysis at $300 \mathrm{MPa}$. However, the peptide profile remained unchanged after HPP of $\beta-\mathrm{Lg}$ at 100-800 MPa [4] and WPI at $400 \mathrm{MPa}$ [25]. HPP treatment of $\alpha$-casein at $200 \mathrm{MPa}$ and $600 \mathrm{MPa}$ for 5 and $15 \mathrm{~min}$ had the highest pepsin digestibility at $200 \mathrm{MPa}$ for $5 \mathrm{~min}$ [26], and no significant change in gastric digestion of whole milk was observed after HPP at $600 \mathrm{MPa}-5 \mathrm{~min}$ [27].

When it comes to food digestion, in addition to the composition and physicochemical characteristics of the food, physiological capability of human gastrointestinal tract play a significant role in the bioaccessibility of nutrients. Clinical studies have shown that the ability of the human body to disintegrate food and secrete of digestive enzymes significantly decreases with increasing age [28-32]. Taking into account this knowledge and inspired by the model developed by Levi and Lesmes [33], we implemented a static in vitro gastric model in our previous work for the elderly [34], in which digestion of major milk proteins in two commercial UHT and pasteurized milks was investigated following the formation pattern of peptides, which was significantly different in the adult and elderly models. The elderly model, together with the standard static gastric model for adults developed in INFOGEST [35], are employed in this work to investigate the peptide profile of milk proteins after HPP treatment.

Considering the potential of HPP in modulating protein structure, it can have an impact on degradation pattern of these proteins into peptides during digestion, since proteins conformation can affect the enzyme's accessibility to the protein's active site. Nevertheless, such studies are scarce in the literature, and there is a knowledge gap on the correlation of protein structure and their digestibility, especially regarding a complex matrix such as milk. To the best of the authors' knowledge, application of HPP on milk and comparison of the subsequent digestion of proteins in elderly and adults in vitro gastric models as in the current study has not been reported before. Therefore, the objective of this study is to investigate the effect of HPP on in vitro gastric digestion of proteins in two models of adults and the elderly in comparison to raw non-treated bovine milk as control. This knowledge will support the development of protein-rich products for the elderly with modulated and customized structures tailored to increase digestibility, and thus bioaccessibility, of milk proteins.

\section{Materials and Methods}

\subsection{Materials}

Fresh raw bovine whole milk was collected from a local dairy (Mannerup Møllegård, Osted, Denmark). On the same day, skimming was carried out using a Milky FJ 130 ERR fat separator at $\sim 50{ }^{\circ} \mathrm{C}$ (Janschitz GmbH, Althofen, Austria). The composition of the milk was determined on the same day before and after skimming by MilkoScan FT2 (Foss, Hillerød, Denmark) and the milks were kept at $5{ }^{\circ} \mathrm{C}$ until the following day for HPP treatments.

\subsection{High-Pressure Treatments}

After skimming, $30 \mathrm{~mL}$ of milk samples were completely filled into narrow-mouth low-density polyethylene bottles (VWR international, Radnor, PA, USA) with lids and vacuum-packed in plastic bags (PA/PE 20/70, 32 oxygen $\mathrm{cm}^{3} / \mathrm{m}^{2} \mathrm{~d}$ bar at $23^{\circ} \mathrm{C}$ and $75 \%$ $\mathrm{RH}, \mathrm{SFK}$, Hvidovre, Denmark). The bags were placed into the HPP chamber filled with water (Avure Technologies AB, Vesterås, Sweden) and pressurized at three conditions of $400 \mathrm{MPa}$ for $15 \mathrm{~min}, 600 \mathrm{MPa}$ for $5 \mathrm{~min}$, and $600 \mathrm{MPa}$ for $15 \mathrm{~min}$, while the temperature was set to $10^{\circ} \mathrm{C}$. The conditions were chosen to obtain HPP milks with three levels of protein aggregation. HPP treatments were conducted in two independent trials for each condition; thus, six HPP trials were performed. Subsequently, the samples were stored at $5{ }^{\circ} \mathrm{C}$ until analysis by sodium dodecylsulphate-polyacrylamide gel electrophoresis (SDS-PAGE). 


\subsection{Protein Composition Analysis by Gel Electrophoresis}

For the SDS-PAGE analysis in both reducing and non-reducing conditions, $50 \mu \mathrm{L}$ milk was mixed with $950 \mu \mathrm{L}$ buffer ( $50 \mathrm{mM}$ Tris buffer containing $1 \%$ SDS, pH 8.0). Then, $65 \mu \mathrm{L}$ of the diluted sample was mixed with $25 \mu \mathrm{L}$ NuPAGE LDS sample buffer and either $10 \mu \mathrm{L}$ 1 M DTT (Invitrogen, Naerum, Denmark) for reducing and Milli-Q water for non-reducing conditions. Proteins were separated using a 4-12\% NuPAGE Novex Bis-tris gel using $5 \mu \mathrm{L}$ of the prepared samples. Spectra ${ }^{\mathrm{TM}}$ Multicolor Broad range protein ladder (ThermoFisher Scientific, Waltham, MA, USA) was also loaded to the gel ( $5 \mu \mathrm{L})$. Electrophoretic separation was carried out applying a voltage of $200 \mathrm{~V}$ in cassettes containing cold MOPS SDS running buffer (Invitrogen, Naerum, Denmark). Afterward, staining of the gel was done using Coomassie Blue (100 $\mathrm{mL}$ equilibrium buffer and $1 \mathrm{~mL}$ brilliant blue) on a rocking shaker (Buch \& Holm A/S, Herlev, Denmark) overnight. The gels were transferred to Milli-Q water for destaining. The gel was scanned using an Epson Perfection V750 pro scanner (Epson, Nagano, Japan). Semi-quantification of the identified bands was performed using image analysis software (TotalLab 100, Nonlinear Dynamics, Durham, NC, USA).

\subsection{In Vitro Gastric Digestion for Adults and the Elderly}

Eight samples of milk including two raw milks and six HPP treated samples $(3 \times 2)$ were subjected to in vitro digestion. Digestion experiments were conducted in duplicate for each sample; thus a total of 32 digestion experiments (16 experiments using the adult and 16 experiments using the elderly model) were performed. Sampling was done after $0,5,10$, and $30 \mathrm{~min}$ of gastric digestion into $2.0 \mathrm{~mL}$ Eppendorf tubes containing $20 \mu \mathrm{L}$ Pepstatin A to inactivate the enzyme (Sigma-Alrich, St. Louis, MO, USA, cat. no. P5318). Pepstatin A solution $(0.5 \mathrm{mg} / \mathrm{mL})$ had been prepared in methanol-acetic acid 9:1. Thus, a total of 128 samples ( 4 milk types $\times 2$ replicates $\times 2$ models $\times 4$ time points $\times 2$ replicates) were immediately transferred to $-80^{\circ} \mathrm{C}$ freezer until further analysis by LC-MS.

The adult digestion was performed following INFOGEST protocol, the standardized consensus for static digestion [35]. Ten milliliters of milk and $10 \mathrm{~mL}$ pre-warmed-up $\left(37^{\circ} \mathrm{C}\right)$ SSF (simulated salivary fluid) without $\alpha$-amylase in screw-capped glass bottles were placed on a magnetic stirrer mixer at $200 \mathrm{rpm}$ (Cimarec i Poly 15 and Multipoint Stirrers, Thermo Electron Corporation, Waltham, MA, USA) inside an incubator (Binder, Citrotek ApS, Hillerrød, Denmark) at $37^{\circ} \mathrm{C}$ for $2 \mathrm{~min}$. The oral solution was then mixed with $15 \mathrm{~mL}$ pre-warmed up $\left(37^{\circ} \mathrm{C}\right) \mathrm{SGF}$ (simulated gastric fluid), $10 \mu \mathrm{L} 0.3 \mathrm{M} \mathrm{CaCl}_{2}\left(37^{\circ} \mathrm{C}\right)$, and $0.590 \mathrm{~mL}$ Milli-Q water while being mixed at $200 \mathrm{rpm}$. The $\mathrm{pH}$ was then reduced to 2.9 using $1 \mathrm{M} \mathrm{HCl}$ and $4 \mathrm{~mL}$ pepsin solution $(2000 \mathrm{U} / \mathrm{mL})$ from porcine gastric mucosa (Sigma-Aldrich, cat. no. P7012, $\geq 2500$ units $/ \mathrm{mg}$ protein) was added to the bottle while on the stirrer (200 rpm). The $\mathrm{pH}$ was kept constant at $3.0 \pm 0.1$ using $1 \mathrm{M} \mathrm{HCl}$ and $1 \mathrm{M} \mathrm{NaOH}$.

The elderly digestion was conducted using our previously described protocol [34]. Following the oral phase as described above for the adult digestion but at $100 \mathrm{rpm}, 15 \mathrm{~mL}$ SGF $\left(37^{\circ} \mathrm{C}\right), 10 \mu \mathrm{L} \mathrm{CaCl} 2\left(37^{\circ} \mathrm{C}\right)$, and $1.8 \mathrm{~mL}$ Milli-Q water were added. The $\mathrm{pH}$ was adjusted to 2.9 , and $2.8 \mathrm{~mL}$ porcine pepsin $(1400 \mathrm{U} / \mathrm{mL})$ was added to the bottle while being mixed on the stirrer $(100 \mathrm{rpm})$ inside the incubator at $37^{\circ} \mathrm{C}$. The $\mathrm{pH}$ was kept constant at $3.0 \pm 0.1$ using $1 \mathrm{M} \mathrm{HCl}$ and $1 \mathrm{M} \mathrm{NaOH}$.

\subsection{Proteomic Analysis Using LC-MS}

The analysis was performed following our previously published protocol using an UHPLC+ Ultimate 3000, mounted with C18 column (Aeris Peptide XB-C18, $150 \times 2.1 \mathrm{~mm}$, $1.7 \mu \mathrm{m}, 100 \AA, 40^{\circ} \mathrm{C}$ ) coupled with a Q Exactive Biotech mass spectrometer (both Thermo Fisher Scientific, Roskilde, Denmark) [34]. More detailed information can be found here [34].

\subsection{Data Analysis}

The LC-MS data generated on digested milk samples were processed and analyzed as described before [34]. Peptides were classified into five different groups according to 
the number of amino acids (AA), <10 AA, 11-15 AA, 16-20 AA, 21-30 AA, and >30 AA. Relative mean abundances of each peptide and peptide groups based on their length were calculated from the two replicates used per milk sample type, from HPP or raw milk, at four digestion time points using either adult or elderly models. Univariate one-way ANOVA (with false discovery rate correction of $10 \%$ ) with multiple comparison testing, principal component analysis (PCA) and ANOVA-simultaneous component analysis (ASCA) were applied to evaluate the effects of HPP on milk samples in vitro gastric digestion models of elderly and adults. All data analysis was performed using MATLAB (version R2016b, The MathWorks, Inc., Natick, MA, USA) and in-house scripts written by authors.

\section{Results and Discussion}

\subsection{Characterization of the Milks before Digestion \\ 3.1.1. Milk Composition}

The composition of the untreated raw milk analyzed by Milkoscan is presented in Table 1. The milk was also analyzed after separation of fat; thus, the starting milk for HPP treatments and the subsequent digestion contained $0.1 \% \pm 0.001$ fat.

Table 1. Composition of the untreated raw milk before removal of fat as analyzed by Milkoscan $(n=2)$.

\begin{tabular}{cccccc}
\hline Composition $\%$ & Fat & Protein & Lactose & Total Solid & Solid Non-Fat \\
\hline Raw milk & $5.26 \pm 0.001$ & $3.27 \pm 0.003$ & $4.41 \pm 0.000$ & $14.28 \pm 0.010$ & $9.07 \pm 0.000$ \\
\hline
\end{tabular}

\subsubsection{Denaturation of Milk Proteins after Application of HPP}

In order to assess the effect of HPP treatments on milk proteins before in vitro digestion, and to better interpret the results of subsequent digestion, samples were analyzed by SDS-PAGE gel electrophoresis in non-reducing and reducing conditions (Figure 1).

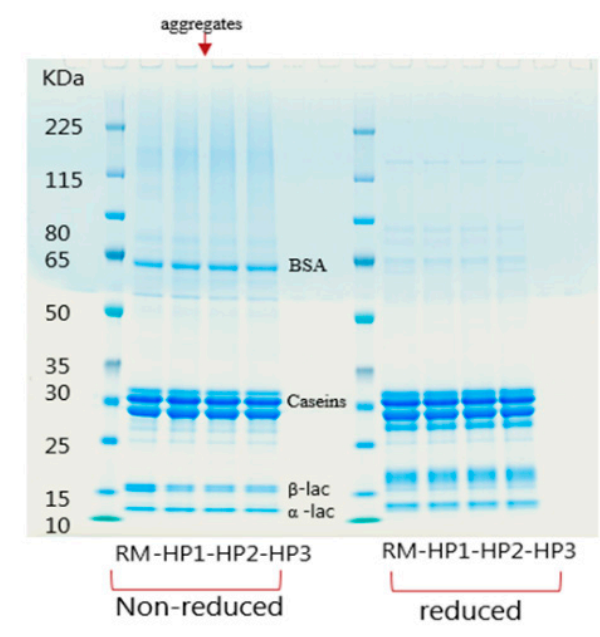

Figure 1. SDS-PAGE gel electrophoresis of raw milk (RM) and high-pressure processing (HPP)treated milks at three conditions-400 MPa $15 \mathrm{~min}$ (HP1), $600 \mathrm{MPa} 5 \mathrm{~min}$ (HP2) and HP 600MPa $15 \mathrm{~min}$ (HP3) - under non-reducing and reducing conditions before in vitro digestion.

As can be seen in Figure 1, there was not any significant change in the intensity of the caseins' bands after application of HPP in either reducing or non-reducing conditions. These results are in agreement with the results of previous studies, which have investigated the denaturation of milk proteins under HPP treatment [27,36]. The same applied for $\alpha$-La and BSA, in which the bands appeared to have the same intensity in various samples; therefore, our results suggest that $\alpha$-La and BSA are resistant to pressures 400-600 MPa. Their resistance to pressures below $400 \mathrm{MPa}$ was previously reported [13].

On the other hand, the intensity of the band for $\beta$ - $\mathrm{Lg}$ showed a remarkable decrease in HPP-treated milks in comparison to the fresh untreated milk (RM). Semi quantification of 
this band indicated that its intensity reduced $52 \pm 2 \%$ in all HPP milks. This is in accordance with a previous study, in which they reported a $50 \pm 6 \%$ decrease in denaturation degree of $\beta$-Lg after HPP treatment at $600 \mathrm{MPa}$ for $5 \mathrm{~min}$ [27]. Nonetheless, we did not observe a significant difference in the denaturation degree of $\beta$ - $\mathrm{Lg}$ between 400 and $600 \mathrm{MPa}$ at 5 or $15 \mathrm{~min}$. Semi-quantification of protein aggregates as indicated on top of the gel in Figure 1 suggested that more aggregates were formed in the two milks subjected to HPP at $600 \mathrm{MPa}$, and these milks contained $\sim 15 \%$ more aggregates compared to the raw milk as well as the sample treated at $400 \mathrm{MPa}$. Bogahawaththa et al. also observed aggregation of milk proteins, mainly $\beta$-Lg and $\mathrm{k}$-casein at $600 \mathrm{MPa}$, but not at $400 \mathrm{MPa}$ [37].

\subsection{In Vitro Digestion of Proteins in Adult and Elderly Model}

Briefly, 1915 peptides were detected using LC-MS, and 1452 of them were present in at least $25 \%$ of milk samples and included in data analysis. The majority of these peptides represented $\beta$-casein (265 peptides), $\alpha \mathrm{s}_{1}$-casein (410 peptides), $\alpha \mathrm{s}_{2}$-casein (266 peptides), $\beta$-lactoglobulin (19 peptides), $\kappa$-casein (95 peptides), and other proteins (Supplementary material). To facilitate the analysis, peptides were categorized based on the number of AA into five groups $-<10,11-15,16-20,21-30$ and longer than $30 \mathrm{AA}-$ as previous work by the authors showed to be a suitable way to compare the digestion of proteins in processed milks in adults with the elderly [34].

In vitro digestion of the fresh raw skim milk using the adult and elderly models is presented in Figure 2, in which the bars are the relative abundance of the peptide groups mentioned above during digestion.
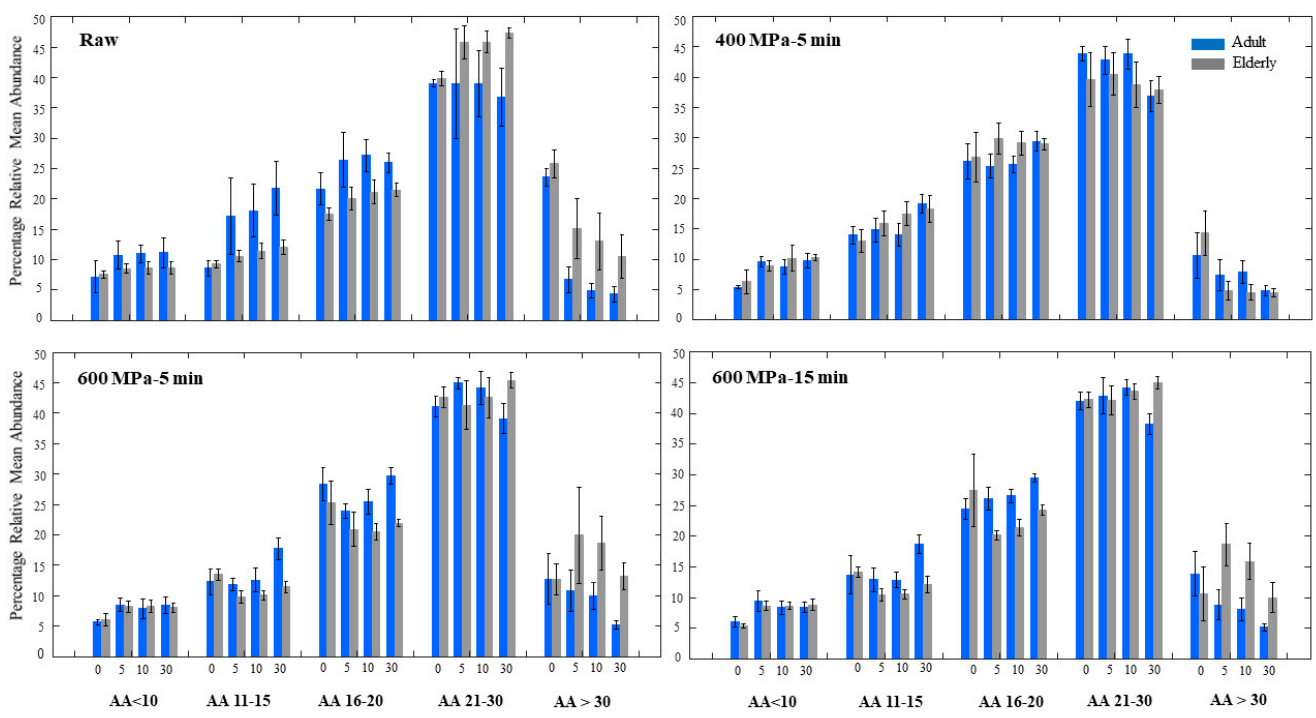

Figure 2. Relative mean abundance (\%) of five groups of peptides categorized based on number of AA at 0, 5, 10 and 30 min gastric digestion of raw milk and HPP treated milks using in vitro adult and elderly models. The bars are the average of two independent replicates and the error bars represent the standard deviations.

One of the marked differences in the gastric digestion of raw milk between the two models was in the higher relative mean abundance of the longer peptides with 21-30 AA and $>30 \mathrm{AA}$. In other words, the raw milk digested for $30 \mathrm{~min}$ using the elderly model generated approximately $47 \%$ peptides with $21-30$ AA in comparison to the corresponding value of $37 \%$ in the adult model. Similarly, $22 \%$ of the peptides in the adult model after 30 min were composed of shorter peptides with 11-15 AA, compared to only 12\% in the elderly model (Supplementary material). These results prove that relative amounts of longer peptides, even after 30 min of digestion, are higher in the elderly model than 
compared to adult model, thus indicating less efficient digestion of the proteins in the elderly model in this milk.

When the same raw milk was pressurized at $400 \mathrm{MPa}$ for $15 \mathrm{~min}$ and similarly digested, the difference between the adult and elderly models was negligible and not significant. An important point worth mentioning here is the significantly higher abundance of peptides originated from the HPP $400 \mathrm{MPa}$ milk in the elderly model at each time point compared to the untreated raw milk. Thus, our results suggest that gastric digestion of milk proteins is more efficient in HPP $400 \mathrm{MPa}$ milk for $15 \mathrm{~min}$ in the elderly, in comparison to the raw milk. This could be explained by the denaturation of the proteins under HPP treatment at $400 \mathrm{MPa}$, and their subsequent structural modification resulting in unfolded but not aggregated structures. Therefore, we hypothesize that accessibility of the proteins to the digestive enzyme, pepsin, increases at this pressure regarding the elderly model. A more opened and unfolded protein structure apparently had a more noticeable effect on elderly digestion, which could be due to the lower concentration of digestive enzyme in this model. In other words, a lower enzyme-to-substrate ratio in the elderly model was an obstacle for efficient enzymatic hydrolysis, which could be overcome by a protein having a more opened structure achieved by HPP at moderate pressure. This explains similar adult and elderly digestion of the proteins in this milk. Structural modification of milk proteins under HPP treatment 150-450 MPa has been previously demonstrated by [6] and thoroughly discussed by [38]. Regarding caseins, destabilization and denaturation at pressures above $300 \mathrm{MPa}$ [11] and aggregation and formation of weak gels occurred at pressures above $600 \mathrm{MPa}$ [37]. However, serum proteins were denatured at pressures above $250 \mathrm{MPa}$ [6] and aggregated at pressures above $500 \mathrm{MPa}$ [38].

In vitro digestion of proteins in HPP milk treated at $600 \mathrm{MPa}$ for $5 \mathrm{~min}$ was significantly higher in the adult model after $30 \mathrm{~min}$ of digestion. Significant differences between the two models were $17 \%$ (11-15 AA) in the adult model vs. $12 \%$ in the elderly, $28 \%$ (16-20 AA) in the adult vs. $23 \%$ in the elderly model, as well as $38 \%$ (21-30 AA) in the adult vs. $44 \%$ in the elderly, and 7\% (>30 AA) in adult vs. 13\% in the elderly model after $30 \mathrm{~min}$. All of these differences show that having a peptide pool with relatively longer peptides after 30 min of digestion in the elderly model indicates a less efficient digestion of the proteins in the elderly model in this milk.

By comparing the milk processed at $400 \mathrm{MPa} 15 \mathrm{~min}$ and $600 \mathrm{MPa} 5 \mathrm{~min}$, we could clearly see that although the proteins digestion is slightly better in HPP 400 MPa milk in adults, the difference is significant but not too large. This difference, however, is more remarkable in the elderly model, and it could suggest that the elderly may show a reduced ability to digest proteins processed at $600 \mathrm{MPa}$ than $400 \mathrm{MPa}$. Again, due to the reduced enzymatic capability of the elderly model, any protein aggregation possibly occurring at pressures such as $600 \mathrm{MPa}$ could impose a more adverse effect on the digestibility of the proteins in this model, rather than in the adult model.

High-pressure processing of the milk at $600 \mathrm{MPa} 15$ min showed a similar peptide pattern as the milk at $600 \mathrm{MPa} 5 \mathrm{~min}$ for both models. According to our results, increasing the pressurization time from 5 to $15 \mathrm{~min}$ at $600 \mathrm{MPa}$ did not have a significant effect on the peptides profile during gastric digestion.

\subsection{Caseins Digestion}

A similar pattern of protein digestion was observed when investigating only caseins, including $\alpha \mathrm{s}_{1}$-casein, $\alpha \mathrm{s}_{2}$-casein, $\beta$-casein, and $\mathrm{k}$-casein, and the digestion of caseins was more efficient in the adult model in various milks (Figure 3). 

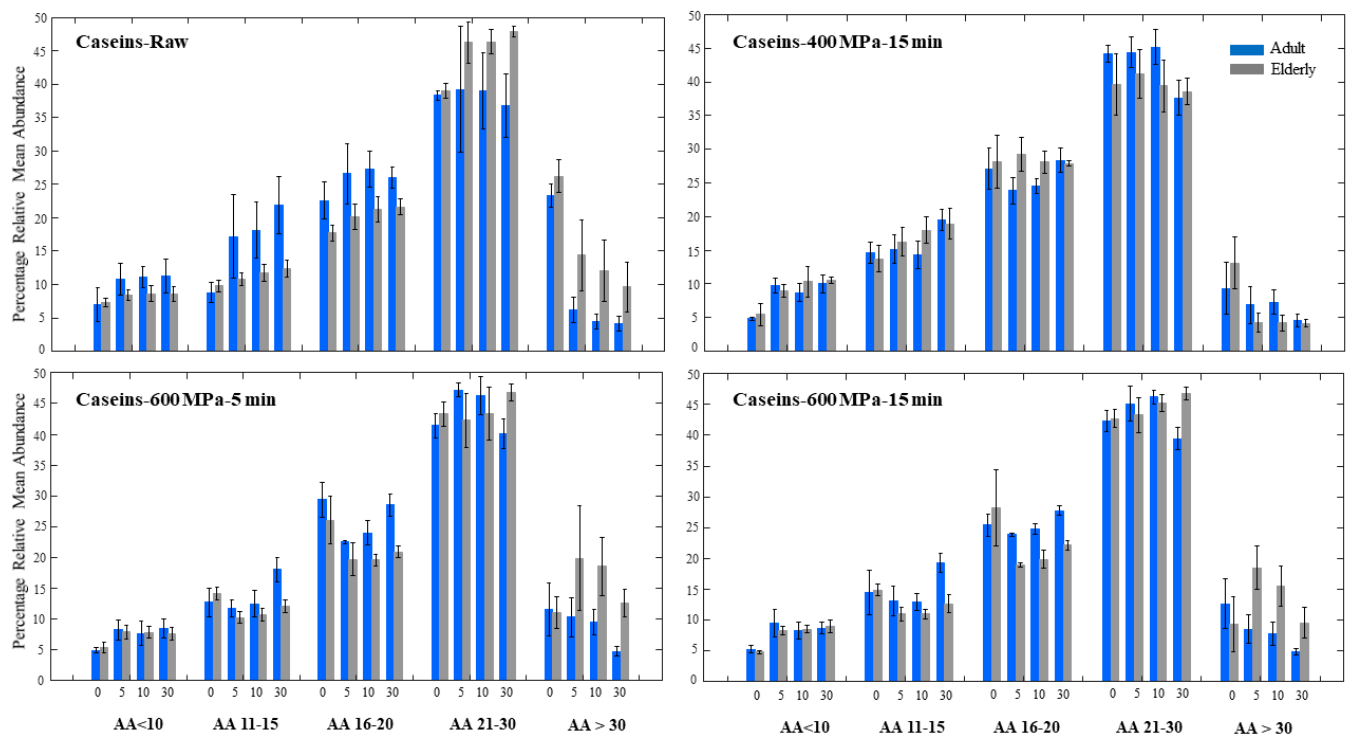

Figure 3. Relative mean abundance (\%) of peptides originated from caseins $\left(\alpha \mathrm{s}_{1}\right.$-casein, $\alpha \mathrm{s}_{2}$-casein, $\beta$-casein, and $\mathrm{k}$-casein) after $0,5,10$, and 30 min gastric digestion of raw milk and various HPP treated milks using the in vitro adult and elderly models. The peptides are categorized based on number of AA into five groups. The bars are the average of two independent replicates, and the error bars represent the standard deviations.

However, digestion of caseins in HPP 400 MPa milk was quite similar in adults and the elderly. Therefore, our results suggest that gastric in vitro digestion of caseins in the elderly in HPP milk processed at $400 \mathrm{MPa} 15 \mathrm{~min}$ is more efficient, producing higher percentages of shorter peptides at the end of digestion compared to other processing conditions. As recently discussed by Orlien, at pressures above $300 \mathrm{MPa}$, dissociation of casein micelles occurs, leading to smaller submicelles [11]. Thus, we conclude that similar digestion of caseins in the elderly model at HPP 400 milk is a result of possible structural dissociation of caseins. As mentioned before, previous studies have shown that at pressures around $600 \mathrm{MPa}$, protein aggregation occurs, especially between $\mathrm{k}$-casein and $\beta$-Lg through thiol disulphide bonds [37]. This may explain better digestion of caseins in the HPP milk at $400 \mathrm{MPa}$, in which aggregation is not expected. In the adult model, however, digestion of caseins was not affected by the intensity of the high pressure applied, and there was not any significant difference among the three high-pressure conditions applied in this work. These results highlight the significance of protein structure and the crucial impact it may have on the protein's digestibility when it comes to a more fragile digestion system as in the case of the elderly. Providing the elderly with proteins with modulated and customized structures using HPP may in fact be a way to overcome the challenge of reduced digestion capability in the elderly.

Studying peptide distribution of each casein before and after gastric digestion provided us a more in-depth understanding of the effect of HPP as well as the digestibility of individual proteins (Figure 4). $\alpha \mathrm{s}_{1}$-casein was the protein with the largest contribution to the peptide pool after digestion, and $59-63 \%$ of all peptides belonged to this protein after digestion. 

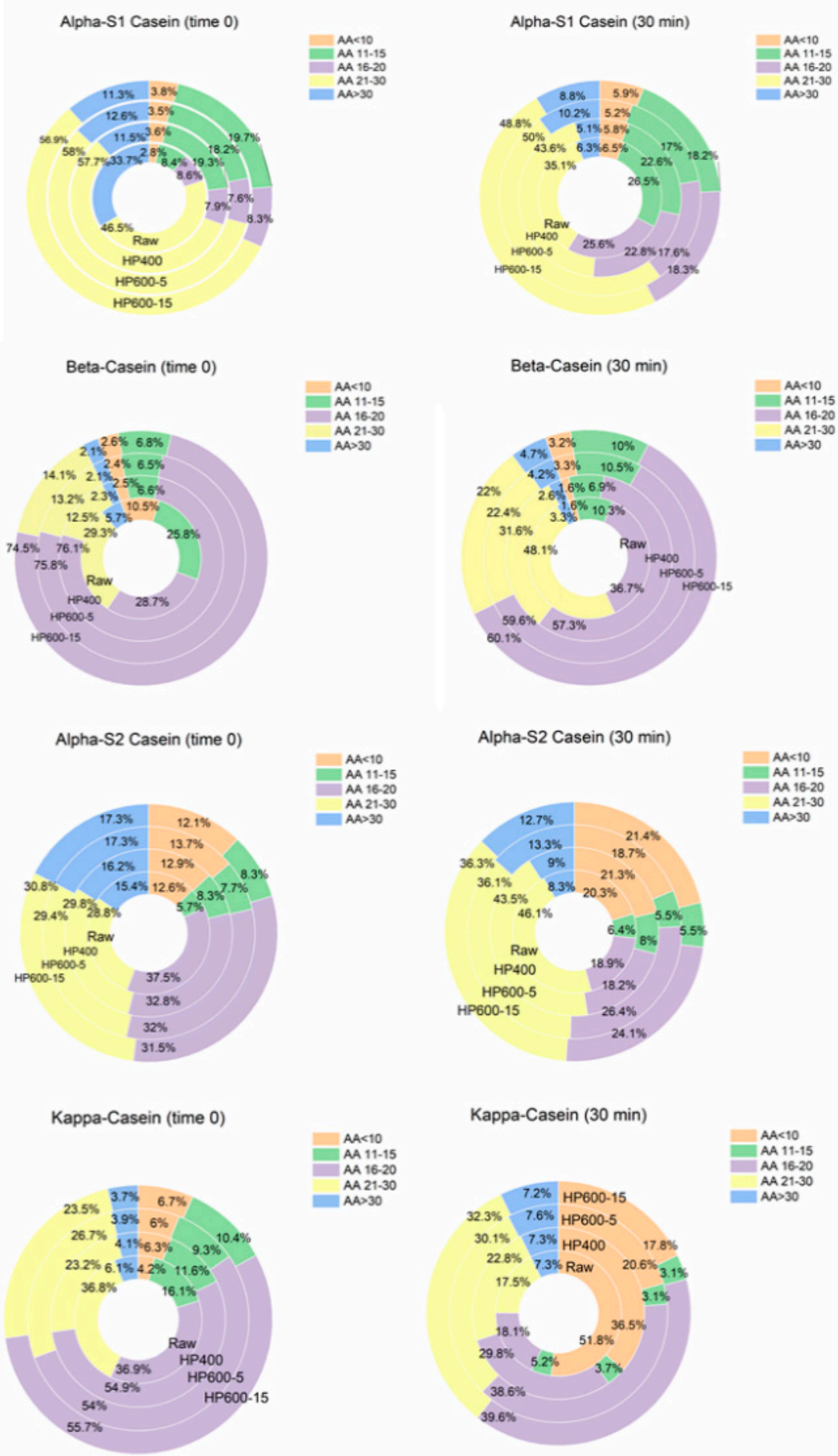

Figure 4. Peptide length distribution in percentage for individual caseins before and after gastric in vitro digestion in raw and three HPP-treated milks, including both adult and elderly.

However, it is important to note that $\alpha \mathrm{s}_{1}$-casein in raw milk before digestion (time 0 ) was composed of $34 \%$ long peptides (AA > 30). The corresponding value in the HPP-treated milks decreased by one-third to approximately 12\% (Figure 4 ).

In a similar observation, $\beta$-casein in raw milk contained $29 \%$ peptides with AA $16-20$, which increased to around 75\% in the HPP milks (time 0 ). Therefore, our findings suggest that application of HPP changes caseins peptide composition and results in peptide pools with relatively shorter peptides in HPP milks, as can be seen in Figure 4. This may be explained by the increase of proteolysis in milk as a result of HPP treatment due to disruption 
of casein micelles and their increased exposure to plasmin, the major proteinase in milk, which has been previously reported in the literature for pressures above $300 \mathrm{MPa}$ [39].

The other point worth highlighting in Figure 4 is the unique peptide composition of individual caseins before and after digestion. In other words, caseins did not show similar digestion pattern to each other; for instance, the contribution of short peptides AA $<10$ was only $1.6-3.3 \%$ in $\beta$-casein and more than $50 \%$ in $k$-casein. The pattern was quite similar in HPP milks and different from raw milk, however. HPP of $\alpha$-casein at $200 \mathrm{MPa}$ for $5 \mathrm{~min}$ showed the highest digestion in a previous study, and increasing the time to $15 \mathrm{~min}$ at $600 \mathrm{MPa}$ decreased the digestibility of this protein from $43 \%$ to $36 \%$ due to the possible formation of aggregates [26]. Our results, however, do not show a significant effect of prolonging the HPP at $600 \mathrm{MPa}$ on in vitro digestion of this protein. This difference could be due to application of SDS-PAGE in the current study, which is not sensitive enough to distinguish the aggregation degree of the two samples pressurized at $600 \mathrm{MPa}$. Furthermore, lower percentages of short peptides in $\mathrm{k}$-casein at pressure $600 \mathrm{MPa}$ after digestion (17-20\%) compared to HPP at $400 \mathrm{MPa}(36 \%)$ suggest its possible participation in aggregation with $\beta$-Lg as reported in the literature [37].

\subsection{Whey Proteins Digestion}

Regarding whey proteins $\beta-\mathrm{Lg}$, immunoglobulin, lactotransferrin, serum albumin, and $\alpha$-La were selected to study their peptide profile during gastric digestion (Figure 5).

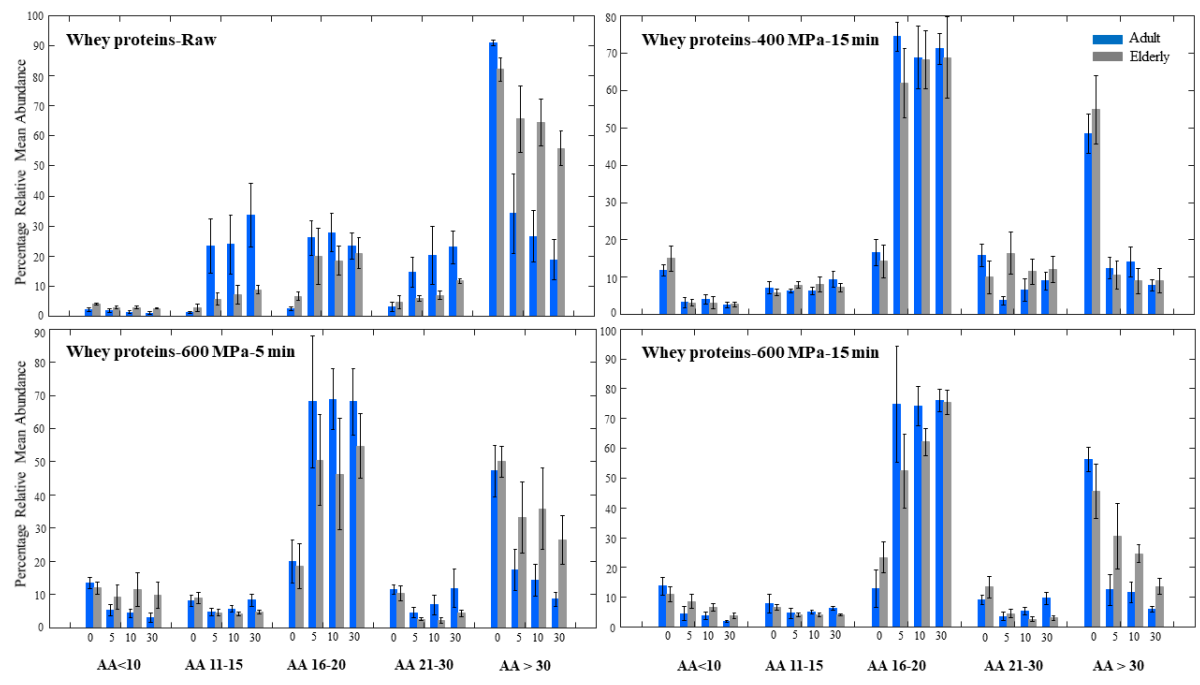

Figure 5. Relative mean abundance (\%) of peptides originated from whey proteins including $\beta-\mathrm{Lg}$, immunoglobulin, lactotransferrin, serum albumin, and $\alpha$-La after $0,5,10$, and 30 min gastric digestion of raw milk and various HPP treated milks using the in vitro adult and elderly models. The bars are the average of two independent replicates and the error bars represent the standard deviations.

The majority of the peptides in the raw milk in both adult and elderly models were long peptides AA > 30, which were more than $50 \%$ in the case of elderly after $30 \mathrm{~min}$, which was the largest difference between the two models. The majority, however, shifted to peptides with 16-20 AA for the HPP milks after digestion; for instance, $80 \%$ of the peptides in HPP milk at 400 MPa were composed of such medium peptides with 16-20 AA (Figure 5). Our findings clearly show more efficient gastric digestion of whey protein in HPP-treated milks compared to the control raw milk. Among the HPP-treated milks, there is a slightly better digestion of whey proteins in HPP 400 milk than the milks processed at $600 \mathrm{MPa}$, which may be due to aggregation of proteins, as previously mentioned [37].

Paying attention to individual whey proteins and their peptide distribution, we notice the positive effect of HPP towards the generation of shorter peptides before digestion (time 0 ) in all whey proteins. In other words, the same proteolysis involving plasmin was observed in caseins as a result of HPP occurred in whey proteins as well. 
As it can be seen in Figure 6, immunoglobulin was composed of more than $80 \%$ long peptides (AA > 30) even after 30 min of digestion, which was contrary to proteins such as $\alpha$-La and lactotransferrin, in which short peptides (AA < 10) formed $80-90 \%$ of the peptides after digestion. In fact, immunoglobulin was the only whey protein with a great percentage of long peptides at the end of digestion in all investigated milks.
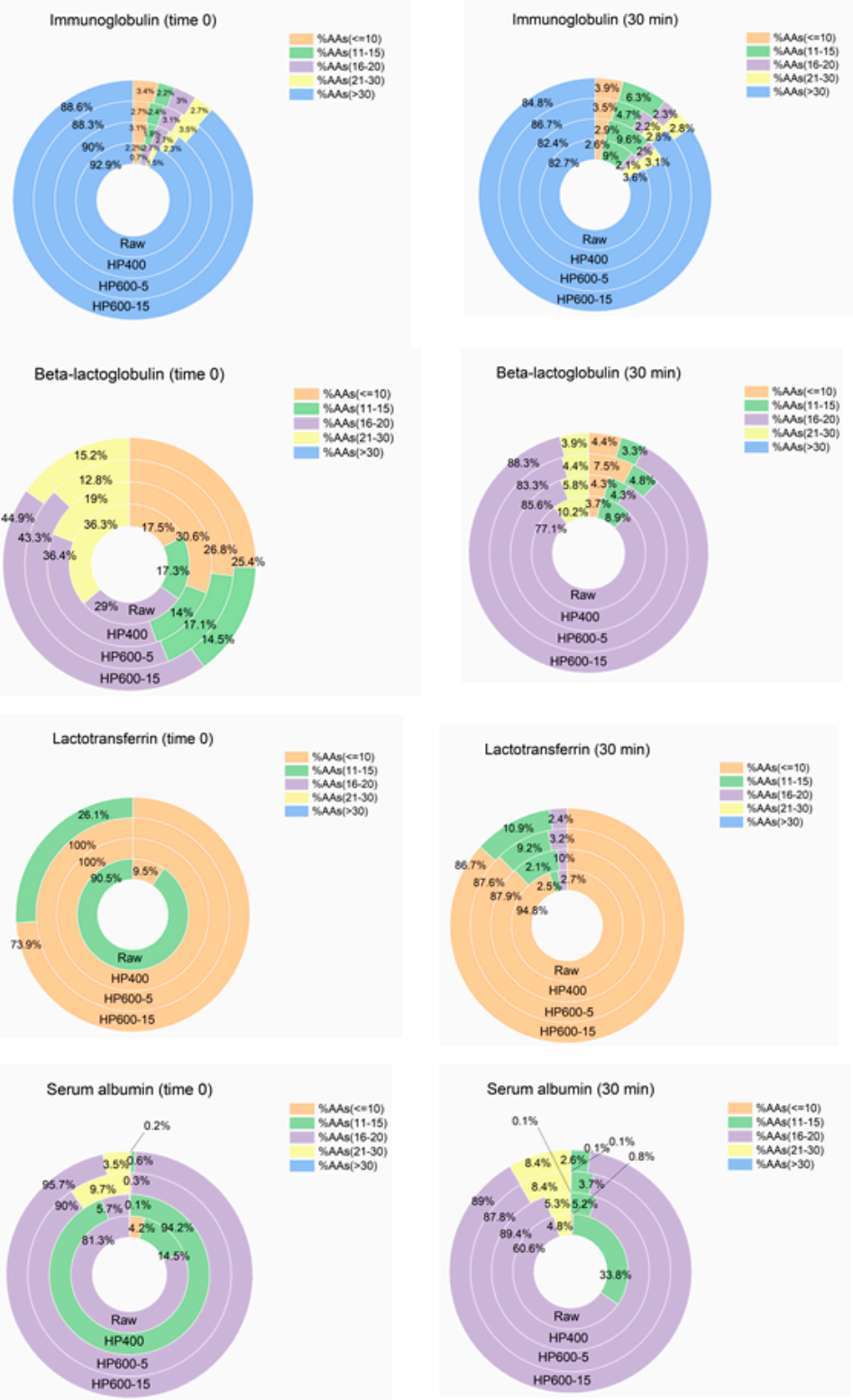

Serum albumin (30 min)
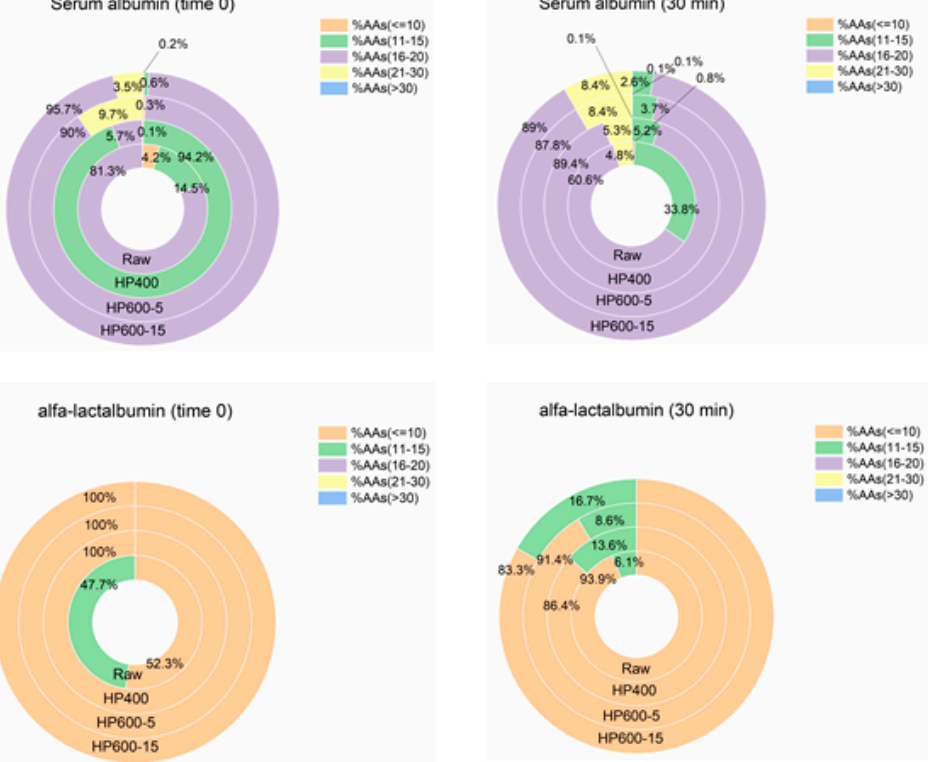

Figure 6. Peptide length distribution of major whey proteins before and after gastric in vitro digestion in raw and three HPP treated milks including both adult and elderly. 
Regarding $\beta-\mathrm{Lg}$, we did not observe a major difference in the digestion of this protein, neither among the HPP-treated milks nor between the adult and elderly models. This protein accounted for $3.1 \%$ of all peptides after digestion, which was the highest contribution to the peptide pool among whey proteins. This is in accordance with the results from a previous study, which showed that HPP of isolated $\beta$-Lg in the range of 100-800 MPa did not have an effect on its peptide profile after $100 \mathrm{~min}$ of trypsin digestion [4]. They also observed a decrease in intact $\beta$-Lg after HPP in SDS-PAGE analysis, the same as in the current study. As there are very few studies in the literature focusing on digestion of HPP milks, comparison of our results with other studies was challenging, considering that most available studies use model systems of isolated proteins and not in a complex matrix such as milk.

\section{Conclusions}

This study investigates effects of HPP at three conditions, $400 \mathrm{MPa} 15 \mathrm{~min}, 600 \mathrm{MPa}$ $5 \mathrm{~min}$ and $600 \mathrm{MPa} 15 \mathrm{~min}$, on gastric digestion of milk proteins and peptides in two in vitro models of adults and the elderly. Proteins and peptides digestion patterns, distribution of peptides based on their length (number of amino acids) from HPP milks were then compared to a digestion pattern of raw untreated milk. Our results showed that gastric digestion was significantly less efficient in the elderly model in investigated milks except for the milk processed at $400 \mathrm{MPa} 15 \mathrm{~min}$, in which the elderly model showed an improved and more efficient digestion to a level similar to adults. Our findings suggest that application of HPP changes peptide composition in caseins and results in peptide pools with relatively shorter peptides. Furthermore, prolonging the pressurization from 5 to $15 \mathrm{~min}$ at $600 \mathrm{MPa}$ did not have a significant effect on the peptide profile of the digested milk proteins, although HPP at $600 \mathrm{MPa}$ resulted in protein aggregation. HPP at $400 \mathrm{MPa} 15 \mathrm{~min}$ showed the most efficient digestion of major milk proteins due to improved hydrolysis, especially caseins, among various milks in this study and should be considered a suitable processing condition to improve bioaccessibility of milk proteins especially regarding products intended for the elderly. Studies including intestinal digestion, especially using whole milk, will provide complementary information and should be considered in the future.

Supplementary Materials: The following are available online at https:/ /www.mdpi.com/article/10 .3390 / foods10040786/s1, Supplementary files S1 and S2 provide peptide distribution of major milk proteins in detail.

Author Contributions: Conceptualization, K.A., B.K., L.A.; methodology, K.A., B.K., C.D.G., L.A.; validation, K.A., B.K., L.A.; formal analysis, K.A., B.K., L.A.; investigation, K.A., L.A.; resources, L.A.; data curation, K.A., B.K., C.D.G., L.A.; writing-original draft preparation, K.A.; writingreview and editing, K.A., B.K., C.D.G., L.A.; visualization, K.A., B.K.; supervision, L.A.; project administration, L.A.; funding acquisition, L.A. All authors have read and agreed to the published version of the manuscript.

Funding: The present study was carried out in the framework of the Platform for Novel Gentle Processing at University of Copenhagen, and was financially supported by the Dairy Rationalization Fund (DDRF) and the Innovation Fund Denmark/ through the FAPESP project Novel AgingTechnologies and solutions to manufacture novel dairy products for healthy aging (grant 2017/01189-0).

Conflicts of Interest: The authors declare no conflict of interest.

\section{References}

1. Voigt, D.D.; Kelly, A.L.; Huppertz, T. High-pressure processing of milk and dairy products. Emerg. Dairy Process. Technol. 2015, 1, 71-92. [CrossRef]

2. Cornell, A. Inventor HPP Process for Dairy Foods. Australian Patent AU, Application number PCT/AU2016/050921, 6 April 2017.

3. Huppertz, T.; Kelly, A.L.; Fox, P.F. Effects of high pressure on constituents and properties of milk. Int. Dairy J. 2002, 12, 561-572. [CrossRef]

4. Maynard, F.; Weingand, A.; Hau, J.; Jost, R. Effect of high-pressure treatment on the tryptic hydrolysis of bovine $\beta$;-lactoglobulin ab. Int. Dairy J. 1998, 8, 125-133. [CrossRef] 
5. Stratakos, A.C.; Inguglia, E.S.; Linton, M.; Tollerton, J.; Murphy, L.; Corcionivoschi, N.; Koidis, A.; Tiwari, B.K. Effect of high pressure processing on the safety, shelf life and quality of raw milk. Innov. Food Sci. Emerg. Technol. 2019, 52, 325-333. [CrossRef]

6. Cadesky, L.; Walkling-Ribeiro, M.; Kriner, K.T.; Karwe, M.V.; Moraru, C.I. Structural changes induced by high-pressure processing in micellar casein and milk protein concentrates. J. Dairy Sci. 2017, 100, 7055-7070. [CrossRef] [PubMed]

7. Anema, S.G.; Lowe, E.K.; Stockmann, R. Particle size changes and casein solubilisation in high-pressure-treated skim milk. Food Hydrocoll. 2005, 19, 257-267. [CrossRef]

8. Anema, S.G.; Stockmann, R.; Lowe, E.K. Denaturation of $\beta$-lactoglobulin in pressure-treated skim milk. J. Agric. Food Chem. 2005, 53, 7783-7791. [CrossRef]

9. Huppertz, T.; Fox, P.F.; Kelly, A.L. Properties of casein micelles in high pressure-treated bovine milk. Food Chem. 2004, 87, 103-110. [CrossRef]

10. Mazri, C.; Sánchez, L.; Ramos, S.; Calvo, M.; Pérez, M. Effect of high-pressure treatment on denaturation of bovine lactoferrin and lactoperoxidase. J. Dairy Sci. 2012, 95, 549-557. [CrossRef] [PubMed]

11. Orlien, V. 1.06-Structural changes induced in foods by HPP. In Innovative Food Processing Technologies; Knoerzer, K., Muthukumarappan, K., Eds.; Elsevier: Oxford, UK, 2021; pp. 112-129.

12. Olsen, K.; Ipsen, R.; Otte, J.; Skibsted, L. Effect of high pressure on aggregation and thermal gelation of beta-lactoglobolin. Milchwissenschaft 1999, 54, 543-546.

13. Lopez-Fandiño, R.; Carrascosa, A.; Olano, A. The effects of high pressure on whey protein denaturation and cheese-making properties of raw milk. J. Dairy Sci. 1996, 79, 929-936. [CrossRef]

14. Kopf-Bolanz, K.A.; Schwander, F.; Gijs, M.; Vergères, G.; Portmann, R.; Egger, L. Impact of milk processing on the generation of pep-tides during digestion. Int. Dairy J. 2014, 35, 130-138. [CrossRef]

15. Lorieau, L.; Halabi, A.; Ligneul, A.; Hazart, E.; Dupont, D.; Floury, J. Impact of the dairy product structure and protein nature on the proteolysis and amino acid bioaccessiblity during in vitro digestion. Food Hydrocoll. 2018, 82, 399-411. [CrossRef]

16. Mat, D.J.L.; Le Feunteun, S.; Michon, C.; Souchon, I. In vitro digestion of foods using pH-stat and the INFOGEST protocol: Impact of matrix structure on digestion kinetics of macronutrients, proteins and lipids. Food Res. Int. 2016, 88, 226-233. [CrossRef]

17. Mulet-Cabero, A.-I.; Mackie, A.R.; Wilde, P.J.; Fenelon, M.A.; Brodkorb, A. Structural mechanism and kinetics of in vitro gastric di-gestion are affected by process-induced changes in bovine milk. Food Hydrocolloid. 2018, 86, 172-183. [CrossRef]

18. Almaas, H.; Cases, A.-L.; Devold, T.G.; Holm, H.; Langsrud, T.; Aabakken, L.; Aadnoey, T.; Vegarud, G.E. In vitro digestion of bovine and caprine milk by human gastric and duodenal enzymes. Int. Dairy J. 2006, 16, 961-968. [CrossRef]

19. Felfoul, I.; Jardin, J.; Gaucheron, F.; Attia, H.; Ayadi, M. Proteomic profiling of camel and cow milk proteins under heat treatment. Food Chem. 2017, 216, 161-169. [CrossRef]

20. Ferreira-Lazarte, A.; Montilla, A.; Mulet-Cabero, A.-I.; Rigby, N.; Olano, A.; Mackie, A.; Villamiel, M. Study on the digestion of milk with prebiotic carbohydrates in a simulated gastrointestinal model. J. Funct. Foods 2017, 33, 149-154. [CrossRef]

21. He, Z.; Yuan, B.; Zeng, M.; Tao, G.; Chen, J. Effect of simulated processing on the antioxidant capacity and in vitro protein digestion of fruit juice-milk beverage model systems. Food Chem. 2015, 175, 457-464. [CrossRef]

22. Nehir El, S.; Karakaya, S.; Simsek, S.; Dupont, D.; Menfaatli, E.; Eker, A.T. In vitro digestibility of goat milk and kefir with a new standardised static digestion method (INFOGEST cost action) and bioactivities of the resultant peptides. Food Func. 2015, 6, 2322-2330. [CrossRef]

23. Rinaldi, L.; Gauthier, S.F.; Britten, M.; Turgeon, S.L. In vitro gastrointestinal digestion of liquid and semi-liquid dairy matrixes. LWT Food Sci. Technol. 2014, 57, 99-105. [CrossRef]

24. Sánchez-Rivera, L.; Ménard, O.; Recio, I.; Dupont, D. Peptide mapping during dynamic gastric digestion of heated and unheated skimmed milk powder. Food Res. Int. 2015, 77, 132-139. [CrossRef]

25. Chicón, R.; Belloque, J.; Alonso, E.; López-Fandiño, R. Immunoreactivity and digestibility of high-pressure-treated whey proteins. Int. Dairy J. 2008, 18, 367-376. [CrossRef]

26. Hu, G.; Zheng, Y.; Liu, Z.; Xiao, Y.; Deng, Y.; Zhao, Y. Effects of high hydrostatic pressure, ultraviolet light-C, and far-infrared treatments on the digestibility, antioxidant and antihypertensive activity of $\alpha$-casein. Food Chem. 2017, 221, 1860-1866. [CrossRef] [PubMed]

27. Liu, G.; Carøe, C.; Qin, Z.; Munk, D.M.; Crafack, M.; Petersen, M.A.; Ahrné, L. Comparative study on quality of whole milk processed by high hydrostatic pressure or thermal pasteurization treatment. LWT 2020, 127, 109370. [CrossRef]

28. Russell, R.M. Changes in gastrointestinal function attributed to aging. Am. J. Clin. Nutr. 1992, 55, 1203S-1207S. [CrossRef] [PubMed]

29. Feldman, M.; Cryer, B.; McArthur, K.E.; Huet, B.A.; Lee, E. Effects of aging and gastritis on gastric acid and pepsin secretion in humans: A prospective study. Gastroenterology 1996, 110, 1043-1052. [CrossRef] [PubMed]

30. Löhr, J.-M.; Panic, N.; Vujasinovic, M.; Verbeke, C.S. The ageing pancreas: A systematic review of the evidence and analysis of the consequences. J. Intern. Med. 2018, 283, 446-460. [CrossRef]

31. Salles, N. Basic mechanisms of the aging gastrointestinal tract. Dig. Dis. 2007, 25, 112-117. [CrossRef]

32. Vellas, B.; Balas, D.; Moreau, J.; Bouisson, M.; Senegas-Balas, F.; Guidet, M.; Ribet, A. Exocrine pancreatic secretion in the elderly. Int. J. Pancreatol. 1988, 3, 497-502.

33. Levi, C.S.; Lesmes, U. Bi-compartmental elderly or adult dynamic digestion models applied to interrogate protein digestibility. Food Funct. 2014, 5, 2402-2409. [CrossRef] [PubMed] 
34. Aalaei, K.; Khakimov, B.; De Gobba, C.; Ahrné, L. Digestion patterns of proteins in pasteurized and ultra-high temperature milk using in vitro gastric models of adult and elderly. J. Food Eng. 2021, 292, 110305. [CrossRef]

35. Minekus, M.; Alminger, M.; Alvito, P.; Ballance, S.; Bohn, T.; Bourlieu, C.; Carrière, F.; Boutrou, R.; Corredig, M.; Dupont, D.; et al. A standardised static in vitro digestion method suitable for food-An international consensus. Food Funct. 2014, 5, $1113-1124$. [CrossRef]

36. Yang, S.; Liu, G.; Munk, D.M.; Qin, Z.; Petersen, M.A.; Cardoso, D.R.; Otte, J.; Ahrné, L. Cycled high hydrostatic pressure processing of whole and skimmed milk: Effects on physicochemical properties. Innov. Food Sci. Emerg. Technol. 2020, 63, 102378. [CrossRef]

37. Bogahawaththa, D.; Buckow, R.; Chandrapala, J.; Vasiljevic, T. Comparison between thermal pasteurization and high pressure processing of bovine skim milk in relation to denaturation and immunogenicity of native milk proteins. Innov. Food Sci. Emerg. Technol. 2018, 47, 301-308. [CrossRef]

38. Olsen, K.; Orlien, V. 11-High-pressure processing for modification of food biopolymers. In Innovative Food Processing Technologies; Knoerzer, K., Juliano, P., Smithers, G., Eds.; Woodhead Publishing: Cambridge, UK, 2016; pp. 291-313.

39. Scollard, P.G.; Beresford, T.P.; Needs, E.C.; Murphy, P.M.; Kelly, A.L. Plasmin activity, $\beta$-lactoglobulin denaturation and proteolysis in high pressure treated milk. Int. Dairy J. 2000, 10, 835-841. [CrossRef] 